\title{
KARAKTERISTIK STOMATA DAN KANDUNGAN KLOROFIL DAUN ANAKAN KAYU CINA (Sundacarpus amarus (Blume) C.N.Page) PADA BEBERAPA INTENSITAS NAUNGAN
}

\section{(Stomatal Characteristic and Chlorophyll Content of Black Pine Seedling Leaf [Sundacarpus amarus (Blume) C.N.Page] at Several Shaded Intensities)}

\author{
Claudia N. S. Karubuy ${ }^{1}$ Aditya Rahmadaniarti ${ }^{1 凶}$ dan Jacobus Wanggai ${ }^{1}$ \\ Jurusan Kehutanan, Fakultas Kehutanan Universitas Papua Manokwari, Papua Barat, \\ 98314. Tlp/Fax: +62986211065. \\ \enulis Korespondensi: Email: aditya_rahmadaniarti@yahoo.com \\ Diterima: 03 Feb 2018| Disetujui: 27 Feb 2018
}

\begin{abstract}
Abstrak
Penelitian ini bertujuan untuk mengetahui pengaruh variasi intensitas naungan terhadap karakteristik stomata dan kandungan klorofil daun anakan kayu cina (Sundacarpus amarus (Blume) C.N.Page). Penelitina ini menggunakan desain rancangan acak lengkap dengan empat tingkat perlakuan intensitas naungan paranet, yaitu kontrol (tanpa naungan), intensitas naungan $40 \%$, intensitas naungan $55 \%$, dan intensitas naungan $75 \%$. Data uji dengan menggunakan analisis variance (ANOVA) dengan selang kepercayaan 95\%. Hasil penelitian memperlihatkan perlakuan intensitas naungan tidak memberikan pengaruh signifikan terhadap karakteristik stomata (jumlah dan kerapatan stomata), dan kandungan klorofil dari jenis Sundacarpus amarus. Ketidakhadiran secara signifikan dari perlakuan yang diberikan ini meperlihatkan bahwa ada pengaruh iklim dan cuaca harian seperti intensitas cahaya $(43,5 \%)$, suhu $\left(27,5^{\circ} \mathrm{C}\right)$, curah hujan $(233,6 \mathrm{~mm})$, and dan kelembaban (83.2\%) yang mana tidak terlalu ekstrim sehingga anakan tumbuhan mampu beradaptasi dengan baik pada kondisi tersebut.
\end{abstract}

Kaata kunci: Sundacarpus amarus, intensitas naungan, karakteristik stomata, kandungan klorofil.

Abstract
This study aims to determine the effect of shade intensity variation on stomata characteristics and chlorophyll content of Black pine seedlings (Sundacarpus amarus (Blume) C.N.Page). The research design was used complete randomized design with four level of shade intensity treatments, controll (without shade), 40\%, 55\%, and 75\%. Data were examined through analysis of variance (ANOVA) of the 95\% confidence level. The result showed that shade intensity treatment did not give significant effect on stomata characteristics (the number of stomata and stomata density), and chlorophyll content of Black pine leaf (Sundacarpus amarus (Blume) C.N.Page). The absence of any significant effect between treatments was thought to be caused by climatic conditions, i.e light intensity $(43.5 \%)$, temperature $\left(27.5^{\circ} \mathrm{C}\right)$, rainfall $(233.6 \mathrm{~mm})$, and moisture $(83.2 \%)$ which is not too extreme, so the tillers were able to adapt well to the condition. Keywords: Black pine, shade intensity, stomata characteristics, chlorophyll content. 


\section{PENDAHULUAN}

Cahaya matahari merupakan sumber utama energi bagi kehidupan, tanpa adanya cahaya matahari kehidupan tidak akan ada. Bagi pertumbuhan tanaman ternyata pengaruh cahaya selain ditentukan oleh kualitas ternyata ditentukan intensitasnya. Pada dasarnya intensitas cahaya matahari akan berpengaruh nyata terhadap sifat morfologi dan fisiologi tanaman. Hal ini dikarenakan intensitas cahaya matahari dibutuhkan untuk berlangsungnya penyatuan $\mathrm{CO}_{2}$ dan air untuk membentuk karbohidrat Lukitasari (2010) dalam Puspitasari dkk. (2012).

Struktur tegakan hutan menciptakan lingkungan cahaya yang beragam bagi jenis tanaman yang hidup di bawah tajuk tegakan. Pertumbuhan tanaman di bawah naungan/tegakan dibatasi oleh ketersediaan cahaya. Kerapatan tajuk akan memengaruhi laju fotosintesis yang berdampak pada produksi biomasa dan produktivitas hasil yang berada di bawah tegakan hutan alam (Rahmadaniarti 2013).

Menurut Suryowinoto (1988) dalam Puspitasari dkk. (2012) mengemukakan bahwa terdapat dua faktor yang mempengaruhi pertumbuhan tanaman, yaitu faktor makro dan faktor mikro. Yang termasuk dalam faktor makro adalah: cahayamatahari, suhu, kelembaban, awan, angin, serta pencemaran udara. Sedangkan faktor mikro meliputi media tumbuh dan kandungan $\mathrm{O}_{2}$ dan $\mathrm{CO}_{2}$ yang adadi udara.

Perlakuan dengan pemberian naungan pada tanaman kayu cina yang toleran terhadap naungan karena cenderung lebih efisien dalam pemanfaatan cahaya. Pada batas naungan tertentu proses fisiologis di dalam tanaman toleran tersebut tidak terlalu dipengaruhi naungan sehingga tanaman tumbuh normal, tidak terjadi etiolasi dan kerebahan yang tentunya tidak mempengaruhi hasil (Puspitasari dkk. 2012).

Pemberian perlakuan naungan pada tanaman kayu cina membutuhkan intensitas cahaya yang cukup. Proses fisiologi tanaman kayu cina dipengaruhi oleh intensitas cahaya yang diserap tanaman juga ditentukan oleh tingkat efisiensi penggunaan cahaya oleh tanaman bersangkutan. Oleh karena itulah, untuk mengetahui bagaimana pengaruh intensitas naungan terhadap proses fisiologi tanaman kayu cina maka penelitian ini dilaksanakan.

Penelitian ini bertujuan untuk mengetahui pengaruh variasi intensitas naungan terhadap karakteristik stomata dan kandungan klorofil daun anakan kayu cina (Sundacarpus amarus (Blume) C.N.Page).

\section{METODE PENELITIAN}

Penelitian karakteristik stomata daun anakan kayu cina (Sundacarpus amarus (Blume) C.N.Page) dilakukan di Laboratorium Silvikultur Fakultas Kehutanan Universitas Papua, sedangkan pengukuran kandungan klorofil dilaksanakan di Laboratorium Fakultas Teknologi Pertanian Universitas Papuaselama empat bulan, yakni dari November 2017 s/d Februari 2018.

\section{Metode Penelitian}

Metode penelitian yang digunakan adalah metode deskriptif dengan teknik observasi. Rancangan penelitian yang digunakan adalah rancangan acak lengkap (complete randomized design), dengan 4 (empat) tingkat perlakuan intensitas 
naungan paranet, yaitu kontrol (tanpa naungan) untuk intensitas cahaya $100 \%$, intensitas naungan $40 \%$ untuk intensitas cahaya $60 \%$, intensitas naungan 55\% untuk intensitas cahaya 45\%, dan intensitas naungan $75 \%$ untuk intensitas cahaya $25 \%$. Tanaman yang digunakan berupa semai kayu cina yang tingginya sekitar 10-15 cm dengan jumlah 6 polybag per tingkat naungan dan setiap perlakuan terdiri dari 3 tanaman (sebagai ulangan).

\section{Prosedur Kerja Penelitian}

Pengamatan karakter fisiologi daunanakan kayucina meliputi:

1. Pengambilan sampel daun dilakukan pada pagi hari yaitu antara pukul 09.00-10.00. Sampel daun diambil secara acak dari setiap perlakuan intensitas naungan. Daun yang diambil adalah daun yang telah berkembang sempurna.

2. Analisis Kandungan Klorofil (mg/l) (Yoshida et al.1997 dalam Sinaga 2005): Daun segar dipotong kecilkecil dan ditimbang sebanyak 5 (lima) gram. Daun tersebut digerus sampai halus dengan mortar dalam aseton $80 \%$ secukupnya. Hasil gerusan kemudian disaring dengan kertas Whatman No. 1 ke dalam labu ukur $100 \mathrm{ml}$. Penggerusan dan penyaringan diulang bila masih ada klorofil yang tersisa. Tambahkan aseton $80 \%$ ke dalam labu ukur sampai mencapai 100 ml, kemudian ambil $5 \mathrm{ml}$ larutan ini dimasukkan ke dalam labu ukur $50 \mathrm{ml}$ dan diencerkan dengan aseton 80\% sampai volumenya $50 \mathrm{ml}$.

3. Jumlah Stomata Daun

Daun anakan kayu cina diolesi kutex bening pada bagian permukaan bawah daun. Safranin dicampur dengan aquades dan diaduk sampai homogen. Larutan safranin tersebut kemudian dituangkan ke dalam petridish. Kutex dikelupas dengan cutter dan dimasukkan ke dalam petridish. Kutex diambil dan diletakkan pada gelas objek yang telah diberi larutan safranin lalu ditutup dengan deglas (cover glasses). Pengamatan dilakukan terhadap 3 sampel tanamanper tingkat naungan dengan menghitung jumlah stomata seluas satu bidang pandang di bawah stereo mikroskop dengan perbesaran $40 \times$.

\section{Variabel Pengamatan}

1. Karakteristik Stomata, terdiri dari:

a. Tipe Stomata

Tipe stomata yang diamati berdasarkan hubungan stomata dengan sel epidermis dan sel tetangga, yaitu apakah tergolong tipe anomositik, tipe anisositik, tipe parasitik, tipe diasitik, tipe aktonositik, dan tipe siklositik.

b. Jumlah Stomata

Jumlah stomata dapat dihitung dan diklasifikasikan menjadi: sedikit (1-50), cukup banyak (51100), banyak (101-200), sangat banyak (201 - 300) dan tak terhingga (301-700).

c. Kerapatan Stomata

Kerapatan stomata dihitung dengan rumus yaitu menghitung jumlah stomata, lalu dihitung kerapatannya dengan rumus sebagai berikut:

Kerapatan stomata $=\frac{\text { Jumlah stomata }}{\text { Luas bidangpandang }}$

Dan diklasifikasikan menjadi kerapatan rendah $\left(<300 / \mathrm{mm}^{2}\right)$, 
kerapatan sedang $\left(300-500 / \mathrm{mm}^{2}\right)$ dan kerapatan yang tinggi $\left(>500 / \mathrm{mm}^{2}\right)$. Luas bidang pandang dapat dihitung dengan menggunakan rumus: $1 / 4 \pi \mathrm{d}^{2}$.

2. Kandungan Klorofil (mg/l) (Yoshida et al. 1997 dalam Sinaga 2005).

Larutan klorofil sebanyak $50 \mathrm{ml}$ diambil dan selanjutnya diukur transmitansinya (T) pada panjang gelombang $(\lambda) 645 \mathrm{~nm}$ dan $663 \mathrm{~nm}$ dengan menggunakan alat spektrofotometer UV-VIS yang kemudian dikonversikan ke absorban dengan rumus: $\mathrm{A}=2-\log \mathrm{T}$. Untuk menghitung kandungan klorofil digunakan rumus sebagai berikut : $\mathrm{Kl} \mathrm{a}=0.0127 . \mathrm{A}_{663}-0.00269 . \mathrm{A}_{645}$ $\mathrm{Kl} b=0.0229 . \mathrm{A}_{645}-0.00468 . \mathrm{A}_{663}$ $\mathrm{K} 1$ total $=\mathrm{Kl} \mathrm{a}+\mathrm{Kl} \mathrm{b}=0.0202 . \mathrm{A}_{645}$ $+0.00802 . \mathrm{A}_{663}$

$\mathrm{Kl} \mathrm{a}=$ klorofil $\mathrm{a} ; \mathrm{Kl} \mathrm{b}=$ klorofil $\mathrm{b}$ $\mathrm{A}_{663}=$ Absorbansi pada $\lambda 663 \mathrm{~nm}$
$\mathrm{A}_{645}=$ Absorbansi pada $\lambda 645 \mathrm{~nm}$

\section{Analisa Data}

Karakter fisiologis (jumlah stomata, kerapatan stomata dan kandungan klorofil) dianalisis dengan analisis varians (ANOVA) pada taraf kepercayaan 95\%, dan uji lanjutan DMRT (Duncan Multiple Range Test) untuk mengetahui respon tanaman kayu cina terhadap intensitas naungan.

\section{HASIL DAN PEMBAHASAN}

\section{Karakteristik Stomata Daun Anakan Kayu Cina (Sundacarpus amarus}

\section{Tipe Stomata}

Berdasarkan hasil pengamatan, stomata daun anakan kayu cina hanya terletak pada bagian bawah permukaan daun (abaksial), dikarenakan pada bagian atas permukaan daun (adaksial) tidak dijumpai stomata.

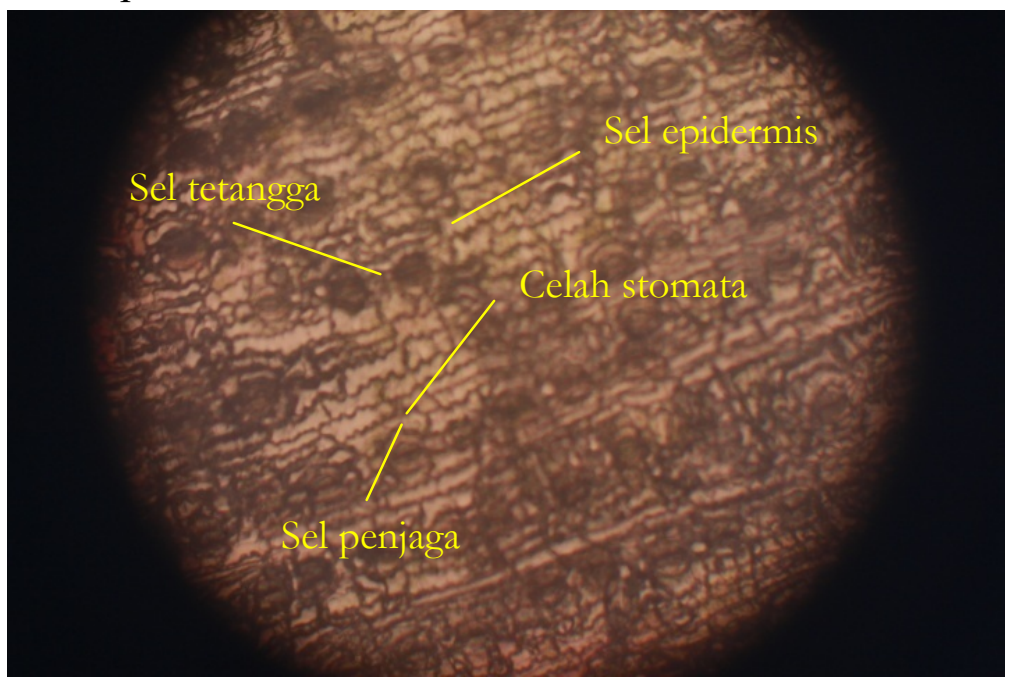

Gambar 1. Tipe stomata daun anakan kayu cina (Sundacarpusamarus (Blume)C.N.Page) pada pembesaran $40 \times$.

Tipe stomata daun kayu cina adalah bertipe 'diasitik', yaitu stomata yang dikelilingi oleh dua sel tetangga dan dinding sel tetangga itu tegak lurus terhadap sumbu melalui panjang sel penutup serta celah (Gambar 1). Jumlah 
lekukan dinding sel epidermis pada kontrol, intensitas naungan 40,55 dan 75\% mencapai 5-12 lekukan, sehingga diduga naungan tidak mengubah jumlah lekukan sel epidermis. Letak stomata satu dengan stomata lain yang berada di naungan kontrol, 40,55, dan 75\% dibatasi 2 sel epidermis. Sel epidermis daun kayu cina memiliki bentuk memanjang dan berlekuk. Hal ini sejalan dengan hasil penelitian Sundari dan Atmaja (2011) yang menyatakan bahwa naungan tidak mengubah tipe stomata pada lima genotipe kedelai yang diuji, yaitu tipe parasitik dan anomositik dengan bentuk sel epidermis yang lonjong dan berlekuk.

Secara umum letak stomata satu dengan tetangganya terhubung seperti rantai dan orientasinya paralel atau sejajar dengan sumbu utama tulang daun. Posisi stomata agak tenggelam dari permukaan epidermis (hipostomatik). Hal ini sejalan dengan Wahidah (2011) dalam Merdekawati (2015) yang menyatakan bahwa ada beberapa tipe stomata berdasarkan lokasi permukaan daun, yaitu: Amphistomatik yaitu jika stoma berada pada kedua permukaan daun (adaksial dan abaksial), Epistomatik yaitu jika posisi stoma hanya terdapat pada permukaan atas epidermis daun, dan Hipostomatik yaitu jika posisi stoma hanya terdapat dipermukaan bawah epidermis daun.

\section{Jumlah Stomata}

Perlakuan variasi intensitas naungan tidak berpengaruh nyata terhadap jumlah stomata dan kerapatan stomata (Tabel 2).

Hal ini diduga karena proses fotosintesis yang terjadi pada intensitas cahaya tersebut kurang maksimal. Tjasyono (2004) dalam Rahmadaniarti (2013) menyatakan bahwa radiasi matahari merupakan faktor penting dalam metabolisme tanaman yang mempunyai zat hijau daun, karena itu produksi tanaman dipengaruhi oleh tersedianya sinar matahari.

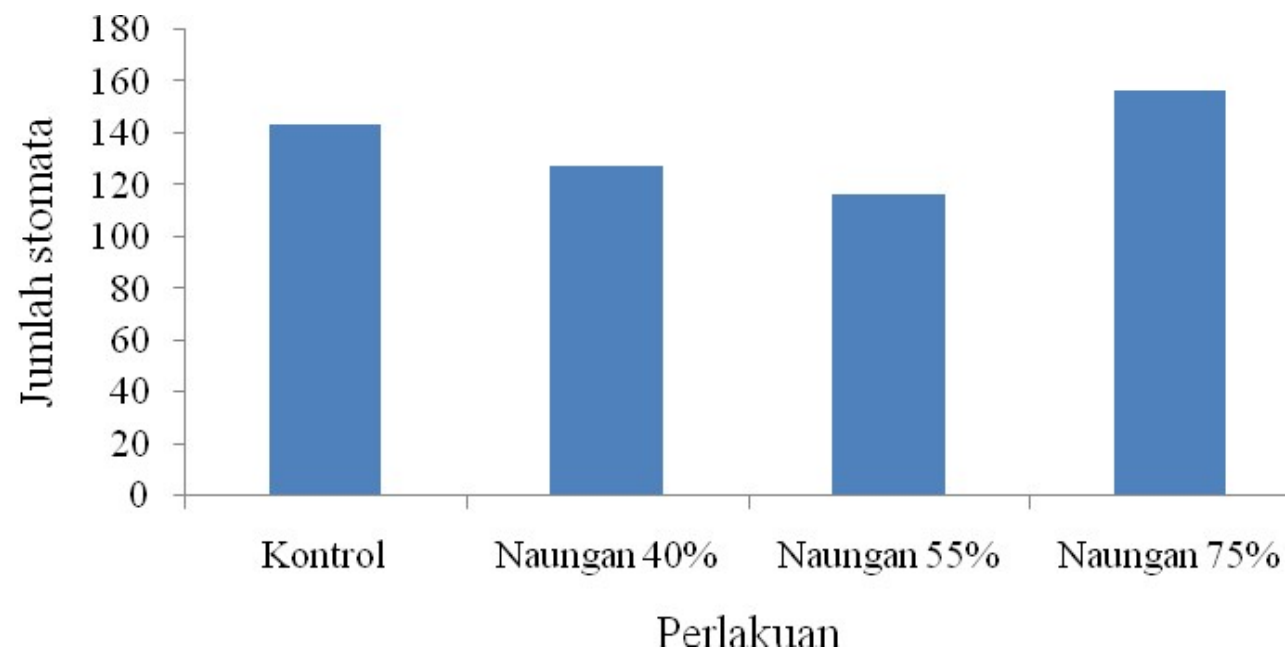

Gambar 2. Rata-rata jumlah stomata daun anakan kayu cina (Sundacarpus amarus (Blume)C.N.Page). 
Gambar 2 menunjukkan bahwa ratarata jumlah stomata daun anakan kayucina (Sundacarpus amarus (Blume) C.N.Page) tertinggi pada perlakuan intensitas naungan 75\% (156,667), dan terendah pada intensitas naungan 55\% (116,556). Jumlah stomata daun kayu cina tersebut tergolong dalam kategori banyak, yaitu $>100$. Hal ini mengindikasikan bahwa jumlah stomata daun kayu cina tidak berbeda nyata, baik pada tanaman yang ternaungi maupun tidak ternaungi. Hal ini sejalan dengan Patterson, (1979) dalam Rahmadaniarti, (2013) yang menyatakan bahwa tidak ada perbedaan yang signifikan dalam resistensi stomata $R$. exaltata pada naungan 25, 60 atau 100\% (kontrol).

\section{Kerapatan Stomata}

Keadaan lingkungan juga mempengaruhi kerapatan stomata. Daun yang tumbuh pada lingkungan kering dan di bawah cahaya dengan intensitas tinggi cenderung mempunyai stomata banyak dan kecil-kecil karena stomata membutuhkan gas karbon dioksida yang banyak untuk proses fotosintesis dibandingkan dengan yang hidup pada lingkungan yang ternaungi (Gambar 3). Kerapatan stomata daun anakan kayu cina (Sundacarpus amarus (Blume) C.N.Page) pada setiap perlakuan disajikan pada Gambar 4. Gambar 4 menunjukkan bahwa rata-rata kerapatan stomata daun anakan kayu cina (Sundacarpus amarus (Blume) C.N.Page) tertinggi pada intensitas naungan $75 \%\left(49,894 / \mathrm{mm}^{2}\right)$, dan terendah pada intensitas naungan $55 \%$ $\left(37,12 / \mathrm{mm}^{2}\right)$. Kerapatan stomata daun kayu cina tersebut masih tergolong dalam kategori rendah, yaitu $<300 / \mathrm{mm}^{2}$. Hal ini sesuai dengan pernyataan Rofiah (2010) bahwa kerapatan stomata diklasifikasikan menjadi kerapatan rendah $\left(<300 / \mathrm{mm}^{2}\right)$, kerapatan sedang $\left(300-500 / \mathrm{mm}^{2}\right)$ dan kerapatan yang tinggi $\left(>500 / \mathrm{mm}^{2}\right)$.
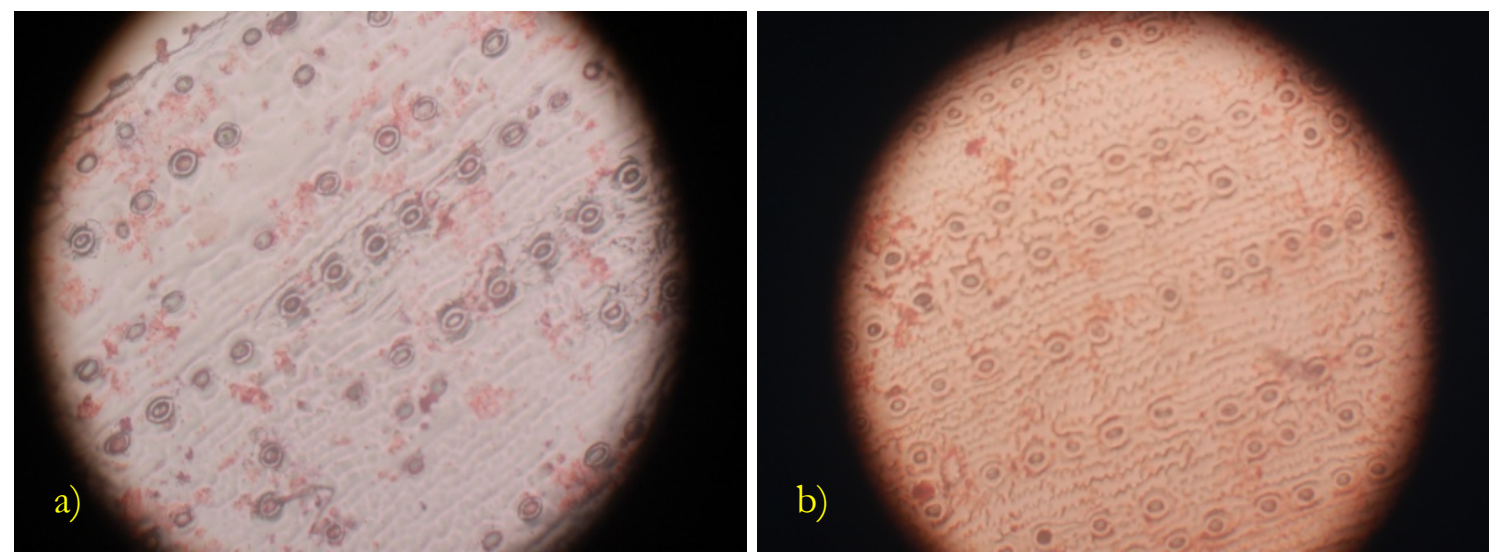

Gambar 3. Stomata daun anakan kayu cina (Sundacarpus amarus (Blume) C.N.Page): a) kontrol (tanpa naungan); b) ternaungi $75 \%$ pada Pembesaran $40 \times$. 


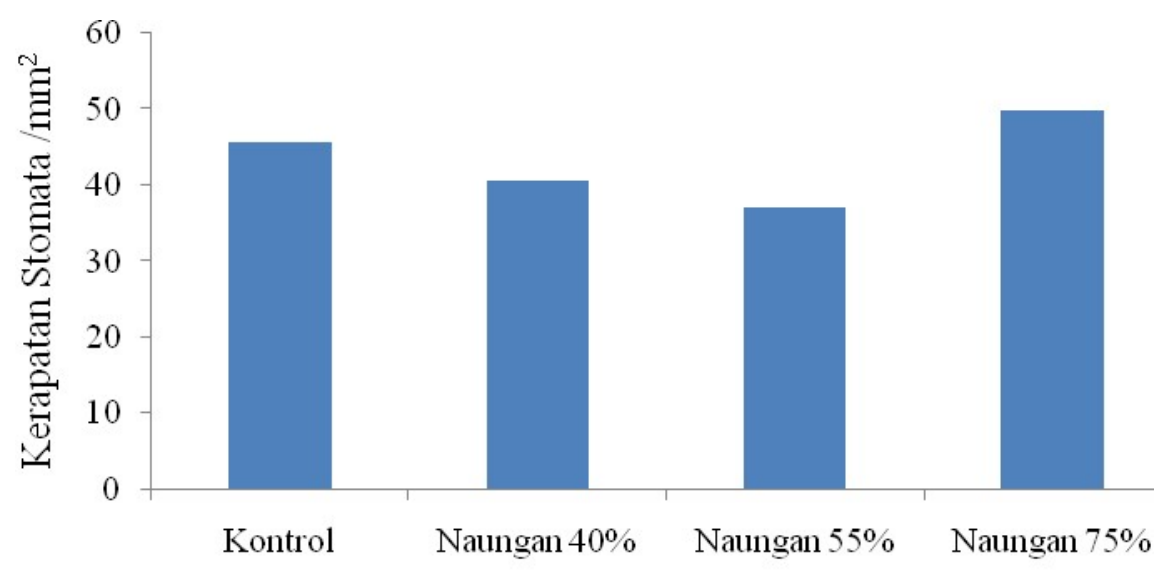

Perlakıan

Gambar 4. Rata-rata kerapatan stomata daun anakan kayu cina (Sundacarpus amarus (Blume)C.N.Page).

Apabila rata-rata kerapatan stomata daun anakan kayu cina (Sundacarpus amarus (Blume) C.N.Page) pada suatu intensitas naungan diketahui dan rata-rata jumlah daun peranakan teridentifikasi, maka jumlah seluruh stomata daun pada anakan kayu cina dapat dihitung dengan pendekatan sebagai berikut:

Jumlah stomata daun pada intensitas naungan $(\mathrm{a})=$

JD X LD $\left(\mathrm{mm}^{2}\right) \times \mathrm{KR} /\left(\mathrm{mm}^{2}\right) \times 0,75$

Dimana JD = Rata-rata jumlah daun satu anakan

LD = Rata-rata luas daun $\left(\mathrm{mm}^{2}\right)$

$\mathrm{KR}=$ Rata-rata kerapatan stomata $/\left(\mathrm{mm}^{2}\right)$

\section{Contoh:}

$$
0,75=\text { Faktor bentuk daun }
$$

Kerapatan stomata daun anakan kayu cina (Sundacarpus amarus (Blume) C.N.Page) pada intensitas naungan tertinggi $\quad 75 \%$ sebesar $49,894 / \mathrm{mm}^{2}$

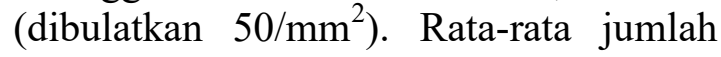
daun kayucina (Sundacarpus amarus (Blume) C.N.Page) pada intensitas naungan $75 \%$ sebanyak 4 daun, dan ratarata luas daun, panjang $10 \mathrm{~cm}(100 \mathrm{~mm})$ dengan lebar $1 \mathrm{~cm}(10 \mathrm{~mm})$ adalah 100 $\mathrm{mm} \times 10 \mathrm{~mm}=1000 \mathrm{~mm}^{2}$.

Maka jumlah stomata daun pada intansitas naungan $75 \%=$

$$
\begin{aligned}
& =4 \times 1000 \mathrm{~mm}^{2} \times 50 / \mathrm{mm}^{2} \times 0,75 \\
& =150.000 \text { stomata }
\end{aligned}
$$

Dengan demikian jumlah stomata sesungguhnya pada intensitas naungan tertentu dapat diketahui. Hal ini dapat membantu menunjukkan perbedaan yang signifikan dari jumlah stomata pada setiap perlakuan intensitas naungan.

Ada kecenderungan bahwa kerapatan stomata daun kayu cina akan meningkat seiring dengan peningkatan intensitas naungan. Kerapatan dan jumlah stomata merupakan proses adaptasi tanaman terhadap kondisi lingkungan. Intensitas cahaya mempengaruhi suhu lingkungan. Semakin tinggi intensitas cahaya, maka suhu lingkungan semakin tinggi. Pembukaan dan penutupan stomata salah satunya dipengaruhi oleh suhu lingkungan.

Suhu udara selama penelitian berkisar antara $27,1{ }^{\circ} \mathrm{C}-27,8{ }^{\circ} \mathrm{C}$, kelembaban udara berkisar antara $81 \%-84 \%$, 
penyinaran matahari berkisar antara $41 \%$ 49\%, dan curah hujan berkisar antara 141 mm-318,2 mm (Badan Meteorologi, Klimatologi, dan Geofisika 2018). Berdasarkan data BMKG tersebut menunjukkan bahwa selama penelitian berlangsung cuaca cukup berawan, sehingga diduga turut mempengaruhi tingkat kerapatan stomata. Hal ini didukung oleh Kimbal (2006) dalam Sundari dan Atmaja (2011) yang menjelaskan bahwa tingkat kerapatan stomata dipengaruhi oleh faktor lingkungan seperti suhu, intensitas cahaya, kelembaban, dan curah hujan. Senada dengan Gregoriou et al. (2007) dalam Paluvi (2015) yang menyatakan bahwa tanaman yang beradaptasi dengan baik terhadap naungan akan mengalami pengurangan kepadatan stomata.

Menurut Miskin et al. (1972) dalam Juairiah (2014) tanaman yang mempunyai kerapatan stomata yang besar akan memiliki laju transpirasi yang lebih tinggi daripada tanaman dengan kerapatan stomata yang rendah. Perbedaan kerapatan stomata menyebabkan perbedaan daya adaptasi untuk bertahan hidup di lahan kering. Hal ini berkaitan dengan adanya kemungkinan bahwa kerapatan stomata dapat memengaruhi dua proses penting pada tanaman, yaitu fotosintesis dan transpirasi (Dobrenz et al. 1969 dalam Juairiah 2014).

\section{Kandungan Klorofil}

Perlakuan variasi intensitas naungan
tidak berpengaruh nyata terhadap kandungan klorofil (Tabel 1). Hal ini diduga karena selama penelitian berlangsung kondisi cuaca cukup berawan, sehingga turut mempengaruhi kandungan klorofil daun anakan kayu cina. Hal ini sejalan dengan Johnston dan Onwueme (1998) dalam Rahmadaniarti (2013) yang menyatakan bahwa dengan semakin tingginya tingkat naungan yang diberikan, tanaman akan melakukan adaptasi dengan meningkatkan efisiensi penangkapan cahaya tiap unit area fotosintetik. Adaptasi yang dilakukan tanaman adalah dengan meningkatkan jumlah klorofil per unit luas daun (akumulasi klorofil).

Gambar 5 menunjukkan bahwa ratarata kandungan klorofil a daun anakan kayu cina tertinggi tertinggi pada perlakun kontrol $(0,019 \mathrm{mg} / \mathrm{l})$, intensitas naungan $75 \% \quad(0,018 \mathrm{mg} / \mathrm{l})$, intensitas naungan $40 \%(0,018 \mathrm{mg} / \mathrm{l})$ dan terendah pada intensitas naungan 55\% (0,016 $\mathrm{mg} / \mathrm{l})$. Kandungan klorofil $\mathrm{b}$ yang tertinggi pada perlakuan kontrol $(0,043$ $\mathrm{mg} / \mathrm{l})$, intensitas naungan $75 \% \quad(0,041$ $\mathrm{mg} / \mathrm{l})$, intensitas naungan55\% $\quad(0,040$ $\mathrm{mg} / \mathrm{l})$, dan terendah pada intensitas naungan $40 \%(0,039 \mathrm{mg} / \mathrm{l})$.

Rata-rata kandungan klorofil total daun anakan kayu cina tertinggi diperoleh pada control $(0,062 \mathrm{mg} / \mathrm{l})$, yang kemudian diikuti intensitas naungan $75 \%(0,059$ $\mathrm{mg} / \mathrm{l})$, dan yang terendah pada intensitas naungan $55 \% \quad(0,057 \mathrm{mg} / \mathrm{l}), \quad$ serta intensitas naungan 40\% (0,057 mg/l). 


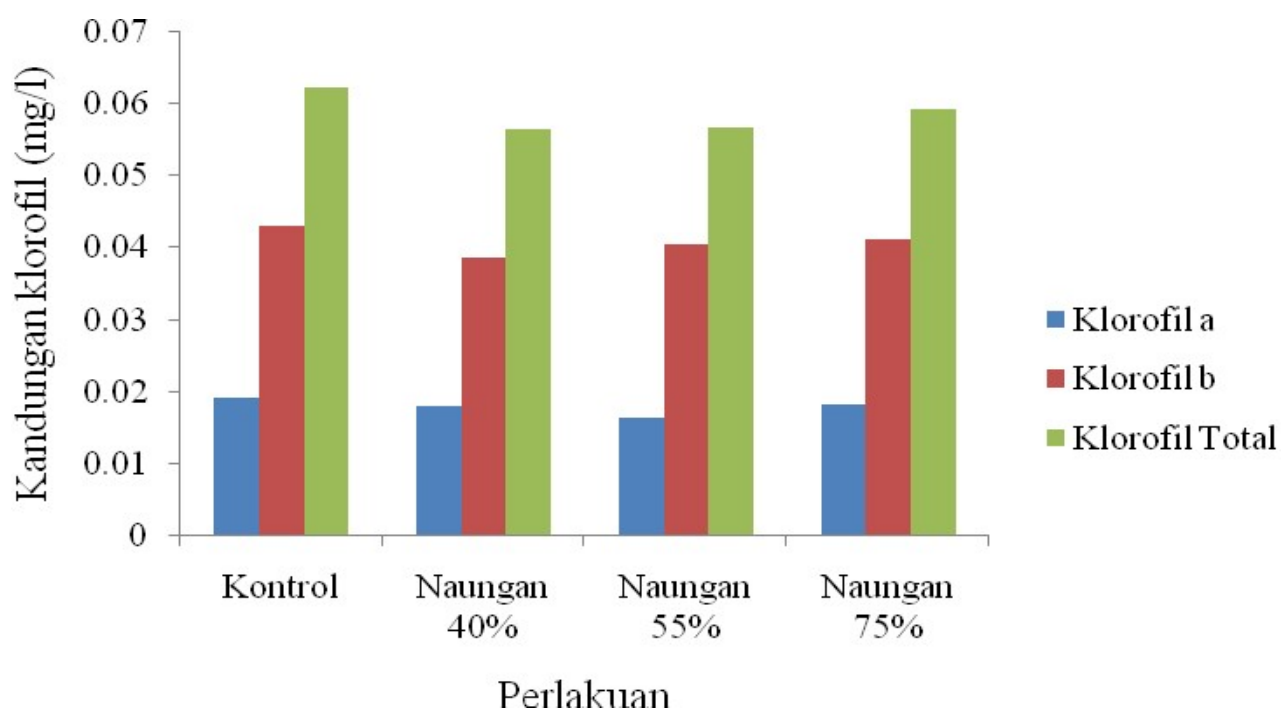

Gambar 5. Rata-rata Kandungan Klorofil Daun Anakan Kayu Cina (Sundacarpus amarus (Blume)C.N.Page).

Klorofil adalah kelompok pigmen fotosintesis yang terdapat dalam tumbuhan, menyerap cahaya merah, biru dan ungu, serta merefleksikan cahaya hijau yang menyebabkan tumbuhan memperoleh ciri warnanya (Anonim 2006 dalam Sumenda dkk. 2011). Tanaman mempunyai dua macam klorofil yaitu klorofil a yang berwarna hijau tua dan klorofil b yang berwarna hijau muda. Klorofil a dan klorofil b paling kuat menyerap cahaya dibagian merah (pada $\lambda$ $600-700 \mathrm{~nm})$, dan paling sedikit menyerap cahaya hijau (pada $\lambda$ 500-600 nm). Lebih lanjut $\mathrm{Ai}$ dan Banyo (2011) menyatakan bahwa klorofil a cahaya yang diserap yaitu cahaya biru-violet dan merah (pada $\lambda$ 673nm), sedangkan klorofil b cahaya yang diserap yaitu cahaya biru dan oranye (pada $\lambda$ 455-640 $\mathrm{nm})$.

Tiga fungsi utama klorofil dalam proses fotosintesis adalah memanfaatkan energi matahari, memicu fiksasi $\mathrm{CO}_{2}$ untuk menghasilkan karbohidrat dan menyediakan energi bagi ekosistem secara keseluruhan. Karbohidrat yang dihasilkan dalam fotosintesis diubah menjadi protein, lemak, asam nukleat dan molekul organik lainnya. Klorofil menyerap cahaya yang berupa radiasi elektromagnetik pada spektrum kasat mata (visible). Cahaya matahari mengandung semua warna spektrum kasat mata dari merah sampai violet, tetapi tidak semua panjang gelombang diserap dengan baik oleh klorofil. Klorofil dapat menampung cahaya yang diserap oleh pigmen lainnya melalui fotosintesis, sehingga klorofil disebut sebagai pigmen utama pusat reaksi fotosintesis (Bahri 2010 dalam Ai dan Banyo 2011).

Berdasarkan pernyataan Stansfield (1991) dalam Ramadhani et al. (2013) merumuskan kriteria rasio adalah sebagai berikut yaitu rasio tinggi $>1$, rasio sedang $=1$, dan rasio rendah $<1$. Dari hasil data yang diperoleh bahwa hasil rasio klorofil $\mathrm{a} / \mathrm{b}=0,436$ menunjukkan bahwa rasio 
klorofil $\mathrm{a} / \mathrm{b}<1$ dan kandungan klorofil $\mathrm{b}$ lebih tinggi dibandingkan dengan klorofil a. Hal ini diduga karena faktor mekanisme adaptasi genetik tanaman toleran terhadap cekaman naungan. Hal ini sesuai dengan pernyataan Kisman (2008) yang menyatakan bahwa tanaman yang toleran naungan mempunyai daun kandungan klorofil $b$ yang lebih tinggi dari klorofil a dengan rasio klorofil $a / b$ yang lebih rendah atau lebih kecil dari 1 .

Rasio klorofil seperti ini diduga merupakan karakter genetik dan fisiologi daun dari tumbuhan yang dapat tumbuh dengan baik di bawah naungan atau adaptasi tanaman terhadap cekaman naungan. Dengan demikian karakter genetik dan fisiologi daun dapat digunakan sebagai petunjuk bahwa kayu cina adalah tumbuhan yang dapat tumbuh dengan baik dibawah naungan, maupun dapat beradaptasi dengan baik terhadap cahaya.

Berdasarkan hasil pengamatan, warna daun anakan kayu cina menunjukkan bahwa perlakuan variasi intensitas naungan secara langsung berpengaruh terhadap karakteristik warna daun anakan kayu cina. Hal ini terlihat dari warna daun anakan kayu cina yang tumbuh pada tanaman kontrol (tanpa naungan) cenderung berwarna hijau muda, dan luas permukaan daun kecil berbeda dengan warna daun pada intensitas cahaya $40 \%$, $55 \%$, dan intensitas cahaya $70 \%$ yang cenderung berwarna hijau tua, dan luas permukaan daun lebar. Perbedaan warna daun anakan kayu cina ini juga berpengaruh terhadap hasil rasio klorofil $\mathrm{a} / \mathrm{b}$ karena, semakin tingginya tingkat naungan yang diberikan tanaman akan melakukan adaptasi dengan meningkatkan efisiensi penangkapan cahaya tiap unit area fotosintetik. Adaptasi yang dilakukan tanaman adalah dengan meningkatkan jumlah klorofil per unit luas daun (akumulasi klorofil). Berdasarkan hal-hal tersebut di atas dapat diketahui bahwa variasi dalam karakter daun dapat dijadikan sebagai gambaran dari lingkungan cahayanya.

\section{Rekapitulasi Hasil ANOVA Karakteristik Stomata dan kandungan Klorofil}

Tanaman kayu cina (Sundacarpus amarus (Blume) C.N.Page) menunjukkan respon yang berbeda-beda terhadap adanya intensitas naungan seperti disajikan pada (Tabel 1).

Tabel 1. Rekapitulasi hasil analisis varian (ANOVA) karakteristik stomata dan kandungan klorofil pada beberapa tingkat intensitas naungan.

\begin{tabular}{|l|c|}
\hline \multicolumn{1}{|c|}{ Parameter } & F hitung \\
\hline Jumlah stomata & $3.860^{\mathrm{ns}}$ \\
Kerapatan stomata & $3.860^{\mathrm{ns}}$ \\
Kandungan Klorofil Total & $1.042^{\mathrm{ns}}$ \\
\hline
\end{tabular}

Ket $: *=$ berpengaruh nyata $(0,05) ; \mathrm{ns}=$ tidak berpengaruh nyata

DAFTAR PUSTAKA

Ai NS dan Banyo Y. 2011. Kosentrasi klorofil daun sebagai indikator kekurangan air pada tanaman. Manado: Universitas Sam Ratulangi Manado. Vol 11 (2): 8 halaman. Diunduh pada: 
http://ejournal.unsrat.ac.id. (5 Maret 2017).

Badan Meteorologi, Klimatologi, dan Geofisika. 2018. Data iklim di Manokwari. (tidak dipublikasikan).

Juairiah L. 2014. Studi karakteristik stomata beberapa jenis tanaman revegetasi di lahan pascapenambangan timah di bangka. UPT Balai Konservasi Tumbuhan, Kebun Raya Cibodas-LIPI. Vol 7 (2): 6 halaman. Diunduh pada: http://widyariset.pusbindiklat.lipi.go.i d. (7 Maret 2018).

Kisman, Trikoesoemaningtyas, Sobir, Khumaida N dan Sopandie D. 2008. Pola pewarisan adaptasi kedelai (Glycine $\max$ L. Merrill) terhadap cekaman naungan berdasarkan karakter morfo-fisiologi daun. Fakultas Pertanian Universitas Mataram. Nusa Tenggara Barat. Diunduh pada: http://download.portalgaruda.org. (27 April 2018).

Merdekawati RP. 2015. Jumlah dan ukuran stomata pada daun glodokan (Polyalthia longifolia) di jalan Tun Abdul Razak dan di area Kampus UIN Alauddin Makassar. Skripsi Fakultas Sains Teknologi UIN Alauddin Makassar. Makassar. Diunduh pada: http://repositori.uinalauddin.ac.id. (8 Mei 2018).

Paluvi N, Mukarlina dan Linda L. 2015. Struktur anatomi daun, kantung dan sulur Nepenthes gracilis Korth. yang tumbuh di area intensitas cahaya berbeda. Jurnal Protobiont, IV (1): 103-107. Diunduh pada: http://jurnal.untan.ac.id. (6 April 2018).

Puspitasari E, Kristianitas dan Putri K. 2012. Pengaruh intensitas cahaya matahari terhadap pertumbuhan tanaman kedelai (Glycine max). Institut Keguruan dan Ilmu Pendidikan PGRI. Madiun. Diunduh pada: https://www.academia.edu. (20 Oktober 2017).

Rahmadaniarti A. 2013. Adaptasi morfologi dan fisiologi tanaman porang (Armorpophallus oncophyillus) terhadap variasi intensitas cahaya dan jenis penaung. Tesis Program Ilmu Kehutanan Fakultas Kehutanan Universitas Gadjah Mada Yogyakarta. (Tidak Dipublikasikan).

Ramadhani F, Putri LAP dan Hasyim H. 2013. Evaluasi karakteristik beberapa varietas kedelai (Glycine $\max$ L.Merill) hasil mutasi kolkisin M2 pada kondisi naungan. Fakultas Pertanian USU. Medan. Vol. 1 (3). Diunduh pada: https://media.neliti.com. (27 April 2018).

Rofiah A. 2010. Kajian aspek anatomi daun beberapa varietas kedelai (Glycine maxl) pada kondisi cekaman kekeringan [Skripsi]. Malang (ID): Fakultas Sains dan Teknologi UIN Maulana Malik Ibrahim. Diunduh pada: http://etheses.uin-malang.ac.id. (5 Maret 2018).

Sinaga R. 2005. Tanggap morfologi, anatomi dan fisiologi rumput gajah dan rumput raja akibat penurunan ketersediaan air tanah. Tesis Sekolah Pascasarjana Institut Pertanian Bogor. Download http://repository.ipb.ac.id. (01 November 2017).

Sumenda L, Rampe HL dan Mantiri FR. 2011. Analisis kandungan klorofil daun mangga (Mangifera indica L.) pada tingkat perkembangan daun yang berbeda. Universitas Sam 
Ratulangi. Diunduh pada: https://ejournal.unsrat.ac.id. (5 Maret 2017).

Sundari T dan Atmaja RP. 2011. Bentuk sel epidermis, tipe dan indeks stomata 5 genotipe kedelai pada tingkat

naungan berbeda. Jurnal Biologi Indonesia, Vol VII (1): 67-79. Diunduh pada: http://ejournal.biologi.lipi.go.id. (5 April 2018). 